ANNA RUdNIK

Wydzią Pedagogiki i Psychologi

UNIWERSYTET W BIAŁYMSTOKU

E-MAIL: A.RUDNIK@UWB.EDU.PL

\title{
WYMIARY STAROŚCI I CECHY LUDZI STARYCH W PERCEPCJI DZIECI I MŁODZIEŻY
}

\section{Wstęp}

Starość bezsprzecznie stanowi naturalny etap życia każdego człowieka, a sam fakt narodzin determinuje jej doświadczanie. Nie oznacza to jednak, że myślimy o niej z życzliwością i spokojem oraz przyjmujemy jej nadejście $\mathrm{z}$ przekonaniem i pokorą $\mathrm{w}$ odniesieniu do wartości, które niesie i ograniczeń, które zsyła. A takie ujmowanie starości nie dotyczy jedynie osób starszych, czy też znajdujących się na przedpolu starości, ale większości osób, grup i zbiorowości. Starość stanowi kwestię niejasną, a tym samym powodującą obawy i strach przed jej doświadczaniem. Spoglądając na jej oblicza dostrzegamy zazwyczaj ograniczenia, trudności i niepokoje. Zdecydowanie rzadziej dostrzegamy bogactwo wiedzy i mądrości oraz refleksyjność i spokój, jaki ze sobą niesie. Interpretacja ta nie uwzględnia heterogeniczności starości, tego że faza ta jest wieloznacznie ujmowana i różnie przez osoby starsze przeżywana. Takie selektywne postrzeganie starości, a tym samym ludzi starych powoduje trudność w formułowaniu ogólnych wniosków na ich temat w ogóle.

Z perspektywy nauk społecznych - w dobie szybko postępujących przemian życia społecznego - istotne jest podejmowanie kwestii interpretowania wymiarów starości przez wszystkie generacje. Wiedza, a przez nią świadomość postrzegania ludzi starych w szerszych zbiorowościach, pozwala dostrzec źródła społecznych zachowań oraz zrozumieć mechanizmy ich powstawania. Kwestia ta jest o tyle znacząca, o ile negatywny stereotyp funkcjonujący w społeczeństwie, stanowi odzwierciedlenie sytuacji ludzi 
starych i przedstawia wyobrażenia społeczeństwa, jego stosunek oraz myślenie na temat starości.

Prowadzone analizy pozwalają jednak stwierdzić, iż nie ma zgodności co do postrzegania roli i znaczenia człowieka starego przez młodsze grupy wieku, a tym samym do obiektywnego, wieloaspektowego identyfikowania wymiarów starości poprzez ukazanie jej atrybutów, cech charakterystycznych, możliwości, trudności, obaw i niepokojów. A więc całego repertuaru elementów, składających się na rzeczywisty opis tego etapu życia człowieka. Dodatkowo dostrzega się, że wyłaniający się stereotyp starości i człowieka starego w społeczeństwie jest na ogół mało przyjazny, gdyż budowany na podstawie niewielkiego zbióru jednoaspektowych informacji. Szczególnie niepokojący jest sposób rozumienia i interpretowania starości przez najmłodsze generacje, tj. dzieci i młodzież. Znajdują się oni w okresie życia, w którym kształtowana jest ich tożsamość, system zasad i wartości, budowany jest własny obraz rzeczywistości społecznej, system przekonań i poglądów. Jest to więc czas zbierania różnorodnych doświadczeń, które będą stanowiły odniesienie dla przeżywanych sytuacji i stanów. Dzieciństwo i okres adolescencji to także czas, kiedy można oddziaływać na jednostkę wyjątkowo skutecznie, a więc czas umożliwiający zmianę postaw i wartości. Stąd zagadnienie rozumienia wymiarów starości przez najmłodsze generacje stanowi nie tyle temat istotny do zgłębiania, ile wyzwanie dla jego właściwego, obiektywnego kształtowania.

\section{Starość i jej wymiary w perspektywie gerontologicznej}

Współcześnie nadal do nierozstrzygniętych należą pytania o to, kogo należy uznać za osobę starszą oraz jakie są kryteria starzenia się i starości. Wprawdzie już wiele epok wcześniej dokonywano definiowania starości, rozpatrując ją wielorako, by w wieku XIX przyznać jej status zjawiska społecznego. Zaczęto tworzyć i konstruować różne definicje omawianego okresu życia oraz związanego z nim - starzenia się, co więcej pojęcia te rozpatrywać zaczęto wielowymiarowo, a mianowicie odwołując się do sfery biologicznej, psychologicznej i społecznej funkcjonowania człowieka.

Wielowątkowe i interdyscyplinarne badania nie przyniosły jednak niebudzącej wątpliwości definicji starzenia się i starości, a prezentowane współcześnie definicje starzenia się i starości są jedynie wynikiem przyjętego przez badaczy określonego punktu widzenia. 
Nie budzi wątpliwości, że starzenie się jest procesem dynamicznym, długotrwałym, który rozwija się stopniowo. W jego wyniku powstają w organizmie, obok zmian atroficznych, nowe mechanizmy pozwalające utrzymać jednostkę przy życiu w danych warunkach. Starość zaś definiowana jest jako nieunikniony etap w życiu człowieka o statycznym charakterze [Rembowski, 1984: 24]. Mimo dostrzegalnych różnic, zarówno proces starzenia się, jak i zjawisko starości są ze sobą związane i w pewnym sensie przenikają się wzajemnie, bowiem zmiany zachodzące na skutek procesu starzenia się, te w sferze biologicznej, jak i demograficznej, ekonomicznej i społecznej, prowadzą do etapu życia, jakim jest starość.

Analiza funkcjonujących definicji starości ${ }^{1}$ pozwala stwierdzić, że jest ona na ogół ujmowana jako pewien okres w życiu człowieka, który związany jest ze zmianami zachodzącymi w jego organizmie. Zmiany te powodują obniżenie funkcji życiowych oraz zawężenie obszaru, w jakim możliwa jest adaptacja do zachodzących zmian. Następuje degradacja w sferze osobowości człowieka, wycofanie z kontaktów społecznych, pogłębienie osamotnienia. Mimo iż są to zmiany naturalne, to wydają się być mniej korzystne, bowiem znacznie bardziej regulują funkcjonowanie człowieka niż zmiany zachodzące w organizmie w okresach poprzedzających starość.

Analizując pojęcie starości oraz starzenia się należy wspomnieć, że $\mathrm{w}$ przebiegu obu tych procesów występują różnice osobnicze. Dotyczą one wielu czynników środowiska wewnętrznego oraz zewnętrznego, czyli zdeterminowane są biologicznie, społecznie, kulturowo i psychologicznie. Ujawniają się w różnym czasie u każdego człowieka, w związku z tym nie jest możliwe określenie dokładnego początku starości. Bardzo trudno jest więc jednoznacznie określić moment, kiedy należy traktować człowieka jako starego. W Polsce przyjmuje się, iż człowiekiem starym jest osoba w wieku emerytalnym, czyli osoba, która ukończyła 60 lub 65 rok życia ${ }^{2}$. Światowa Organizacja Zdrowia (WHO) natomiast za początek starości uznaje 60 rok życia. Przyjmowane klasyfikacje nie mają jednak charakteru uniwersalnego, gdyż między ludźmi w tym samym wieku istnieć

1 W niniejszej pracy pojęcie „starość” będzie używane zamiennie z określeniami „późna dorosłość” i „okres jesieni życia”. Wszystkie terminy używane będą jako synonimy słowa „starość”, rozumianego jako końcowy etap życia, a rozpoczynający się w wieku 60 lat.

2 Do 2013 roku wiek emerytalny w Polsce wynosił 60 lat dla kobiet i 65 lat dla mężczyzn. Od stycznia 2013 roku na mocy znowelizowanej ustawy z dnia 17 grudnia 1998 r. o emeryturach i rentach z Funduszu Ubezpieczeń Społecznych (Dz. U. 2004 r., nr 39, poz. 353 z późn. zm.) wiek emerytalny zrównano dla kobiet i mężczyzn oraz wydłużono do 67 roku życia. 
mogą znaczne różnice. Ludzie starzy nie stanowią bowiem jednolitej grupy ani pod względem stanu zdrowia, ani też sprawności psychicznej i fizycznej, czy też sytuacji materialnej. Zmusza to do rozpatrywania starości jako zróżnicowanego okresu życia, w którym następują dalsze zmiany w funkcjonowaniu człowieka. Bezsprzecznie starość niesie za sobą zmiany, które $\mathrm{z}$ trudem dają się ująć w ramy wieku kalendarzowego, a bardziej miarodajne jest opisywanie starości w odniesieniu do funkcjonowania człowieka w kontekście biologicznym, psychicznym oraz społecznym.

Oczywiste wydaje się, że wraz z upływem lat zmniejsza się zdolność przystosowania człowieka do wysiłku fizycznego, do zmian w sposobie odżywiania, do zmian temperatury [Susułowska, 1989: 33]. Organizm człowieka starzeje się i traci zdolności adaptacyjne. Następują zmiany w wyglądzie fizycznym, narządach i systemach regulacyjnych organizmu. W okresie starości ze względu na naturalne, biologiczne zmiany nasilają się odczuwane wcześniej kłopoty ze zdrowiem. Wskazuje się, iż starość cechuje tzw. wielochorobowość. Wśród chorób towarzyszących okresowi starości wymienia się na ogół: chorobę nadciśnieniową, miażdżycę, niedokrwienną chorobę serca, cukrzycę, reumatoidalne zapalenie stawów, choroby kości, a także demencję, chorobę Alzheimera oraz chorobę Parkinsona. Starzenie się biologiczne może jednak wyglądać odmiennie w zakresie różnych funkcji, sprawność fizyczna człowieka starego uzależniona jest bowiem od wcześniejszych etapów życia, ról społecznych, stylu życia, przejawianej aktywności, zachowań prozdrowotnych, a także czynników środowiskowych (tj.: warunków pracy, stresu, stanu środowiska przyrodniczego).

Zmiany te nie tylko wpływają niekorzystnie na fizyczne funkcjonowanie człowieka starego, ale też na jego sprawność psychiczną. Determinują sprawność i sytuację psychospołeczną starszej osoby, przyczyniając się nierzadko do jej społecznej izolacji, depresji i utraty poczucia własnej godności. Część ludzi nie potrafi poradzić sobie ze zmieniającym się ciałem i wykazuje nadmierną, przesadną ostrożność, bądź popada w stany depresyjne [Stuart-Hamilton, 2006: 25-26].

Zmiany psychiczne dotykają sfery osobowości i inteligencji człowieka starego. Wprawdzie wśród psychologów nie ma zgodności w kwestii kierunku i nieuchronności tych przemian, jednak wskazują oni pewne cechy charakteryzujące ludzi starych takie, jak: skłonność do unikania ryzyka, niechęć do zmian, zubożenie emocjonalne, słabnięcie uczucia złości, ograniczenie zdolności twórczych [Szatur-Jaworska, 2006: 52-53]. W kwestii inteligencji zauważa się, iż wraz $\mathrm{z}$ wiekiem pewne jej składowe pogar- 
szają się, kiedy inne pozostają na tym samym poziomie. Człowiek starszy boryka się ze słabnącą pamięcią pierwotną, co utrudnia zapamiętywanie nowych treści, zmniejsza się przerzutność uwagi, następuje spowolnienie psychomotoryczne oraz myślenie abstrakcyjne. Jednak na stałym poziomie pozostaje u osób starszych wiedza, zdolność rozwiązywania codziennych problemów, umiejętność wnioskowania oraz zdolność rozróżniania co jest właściwe, a co nie [Szatur-Jaworska, 2006]. Człowieka starszego charakteryzuje posiadanie bogactwa wiedzy życiowej, która była zdobywana przez cały produkcyjny okres życia i pozwalała na dynamiczną i twórczą pracę, a w okresie starości może być wykorzystana $\mathrm{w}$ innych sytuacjach i traktowana w kategoriach mądrości życiowej.

Starość utożsamia się także z utratą zdolności do pracy zawodowej i okresem emerytury. Przejście na emeryturę jest jedną $\mathrm{z}$ najważniejszych i zarazem najtrudniejszych zmian towarzyszących starości i stanowi zazwyczaj moment przełomowy w życiu. $Z$ wydarzeniem tym wiąże się wiele zmian. Dla części seniorów trudne może okazać się funkcjonowanie w zupełnie nowej rzeczywistości. Pojawia się nie tylko strach przed nową, nieznaną sytuacją, ale także pogorszeniem się sytuacji materialnej, która po przejściu na emeryturę zazwyczaj ulega pogorszeniu. Okres emerytury związany jest także ze zmianą ról, jakie do tej pory ludzie pełnili. Osoba dotąd aktywna zawodowo staje się emerytem, co zmienia zupełnie jej dotychczasową rolę w społeczeństwie. Rola pracownika wiąże się z określonym statusem i prestiżem społecznym, zapewnia przynależność do określonej grupy osób, jest źródłem wielu kontaktów towarzyskich oraz integruje człowieka ze społeczeństwem. Okres emerytury zmusza do przyjęcia nowej roli społecznej, do której trzeba się przystosować.

$\mathrm{W}$ rodzinie okres starości zbiega się $\mathrm{z}$ momentem usamodzielnienia dzieci i pojawienia się wnuków. Małżonkowie mają więcej czasu dla siebie i na sprawy, które wcześniej nie mogły lub nie były realizowane [Klonowicz, 1997: 197] Kontakty z rodziną stają się dla człowieka starszego najważniejszym rodzajem stosunków społecznych, w jakich pozostaje. Powoduje to u osoby starszej gotowość do świadczenia pomocy i niesienia wsparcia swoim bliskim zawsze, gdy tylko zaistnieje taka potrzeba. Osoby starsze często podejmują funkcje opiekuńcze wobec własnych wnucząt, co wynika z ich dyspozycyjności, ale i bliskości zamieszkania.

Także aktywność osób starszych z czasem ulega obniżeniu. Nie ma już konieczności codziennego wykonywania pracy zawodowej i wypełniania obowiązków z nią związanych. Osoby starsze zyskują dużo czasu wolne- 
go, który spożytkować mogą w dowolny sposób [Kamiński, 1965: 23-24], jednak prowadzone analizy wskazują, że nie zawsze sposób spędzania tego czasu pozwala ludziom starszym zaspokajać istniejące potrzeby i wypełniać funkcje czasu wolnego [Halicka, Halicki, 2002: 203-204]. Większość osób starszych prezentuje jednak postawę bierną, a więc daleką od nastawionej na działanie i pozwalającą na realizację swoich pasji i zainteresowań.

Starość - co podkreślają także powyższe dywagacje - ma niejedno oblicze. Uwarunkowana jest wieloma czynnikami, zarówno odnoszącymi się do samej jednostki, jak i zewnętrznymi, na które jednostka nie ma znaczącego, a niekiedy nawet niewielkiego wpływu. I mimo, że sytuacja ta nie wzbudza zaskoczenia wśród osób obcujących z ludźmi starymi, to w opinii ogółu społeczeństwa zazwyczaj nie znajduje odzwierciedlenia. Najbliższe otoczenie seniorów, grupy, w którymi funkcjonują i z którymi obcują, a także szersze zbiorowości na ogół postrzegają starość i doświadczające jej osoby przez pryzmat rzadko przystającego do rzeczywistości oraz mało przychylnego stereotypu. Tym samym opierając się na złożeniu homogeniczności cech towarzyszących okresowi starości oraz ludziom starym, oceniają ten okres życia raczej pejoratywnie, jako pełen trudności i problemów.

\section{Historyczny kontekst postrzegania człowieka starego i starości}

Starość budziła zainteresowanie już w starożytności. W Azji adepci medycyny, w Europie filozofowie zajmowali się tą problematyką już wiele wieków temu. Analiza tekstów źródłowych wskazuje jednak, iż starość nie zawsze budziła zainteresowanie społeczeństw [Minois, 1995].

W starożytności starość stała się zjawiskiem powszechnym, aby budzić zainteresowanie, bowiem „starców było dość wielu, aby dostrzegać ich obecność, nie dość jednak, żeby stanowili problem społeczny" [Minois, 1995: 20]. Ich los i pozycja były uzależnione od zasobów intelektualnych, materialnych i duchowych poszczególnych społeczności. W związku z tym różne zbiorowości inaczej odnosiły się do starości i seniorów. Jedne darzyły ten okres życia szacunkiem i podziwem, inne zaś przepełniała nienawiść. Częściej jednak ludzi starych otaczano szacunkiem $\mathrm{z}$ uwagi na fakt, iż niewielu ludzi dożywało okresu starości, co powodowało, iż „z racji długowieczności spowija ich aura nadprzyrodzonego autorytetu, byli otoczeni czcią i szacunkiem, pełnili ważną rolę społeczną" [Minois, 1995].

Średniowiecze nie przyniosło znaczącej zmiany w stosunku do osób najstarszych. Starością oraz ludźmi starymi nie bardzo interesowały się 
ówczesne społeczności, czego wyrazem był m.in. fakt, iż człowiek stary rzadko stawał się tematem prac artystów i kronikarzy [Minois, 1995: 128]. Historycy twierdzą, iż „w owym brutalnym i pierwotnym świecie starcy musieli być wielką rzadkością" [Minois, 1995: 159]. Uważa się, iż starości przyznano osobowość dopiero na przełomie XIV i XV wieku, kiedy to pozycja ludzi starych została wzmocniona przez rosnący odsetek ludzi w okresie późnej dorosłości oraz zmianę modelu rodziny. O znaczeniu najstarszego pokolenia świadczą zapisy tej treści: „jeśli przed śmiercią nikomu nie zdołali przekazać swej wiedzy, zanikały czynności, z dziada pradziada skrupulatnie wykonywane w gospodarstwie" [Minois, 1995: 233].

Renesans okazał się być okresem bardzo niejednoznacznym w postawie do starości [Sidorczuk, 2011: 326]. Z jednej strony chwalił młodość, pełnię życia i urodę, z drugiej zaś był epoką, w której osobom starszym powierzano najważniejsze stanowiska oraz nie rezygnowano z ich doświadczeń i zdobytej przez lata mądrości. Wyrazem przychylnego stosunku do osób starszych było przypisywanie im najczęściej roli nauczycieli i doradców [Sidorczuk, 2011].

Jean Pierre Bois pisał, iż wiek XVII przyniósł tzw. „ciche potępienie” starości [Bois, 1996: 45], bowiem traktowano ją jako okres pokuty, medytacji, a także przejścia w inny świat. Człowieka starego odsunięto na ubocze, a miejsce które mu przypisano $\mathrm{w}$ społeczeństwie było określane jako niewidoczne. Przestał więc pojawiać się w twórczości owej epoki, a jego rola w rodzinie także uległa zmianie.

Spojrzenie na starość zmieniło się dopiero w wieku XVIII, w którym wskazywano, iż „starość należy szanować, bo starcy mają w sobie coś czcigodnego" [Bois, 1996: 104]. Nie bez znaczenia dla otwarcia się na człowieka starego przez rodzinę był fakt, iż wydłużeniu uległo życie ludzkie i wzrosła liczba osób starszych w ówczesnych społecznościach. Powodowało to, iż zacieśniały się więzi pomiędzy pokoleniami w rodzinie, a wzajemne kontakty cechowały się bliskością. Ówczesny świat określany jest więc czasem wyjścia człowieka starego do rodziny, któremu towarzyszyło odkrycie babć i dziadków [Sidorczuk, 2011: 327]. Nawoływano, żeby człowieka starego kochać i otaczać względami, jakimi powinno się otaczać „starego mędrca”, gdyż starość to czas nabywanej przez lata mądrości i doświadczenia oraz wewnętrznego spokoju i wiedzy.

Wiek XIX był okresem, w którym starość zaczęła być postrzegana jako okres różnorodny oraz uzależniony od wielu czynników, a jednym z nich była sytuacja rodzinna. W owym czasie nastąpiły zmiany $\mathrm{w}$ strukturze społeczeństwa, objawiające się zanikiem dawnych rodzin wielopokole- 
niowych. Przypieczętowało to zmiany w pozycji człowieka starego, które zapoczątkował wiek poprzedni [Sidorczuk, 2011: 328]. Wyraźnie zmalała więc rola dziadków jako edukatorów wnucząt. Mimo to większość ludzi starszych mogła cieszyć się czułością i zainteresowaniem ze strony rodziny. Nadal przypisywana była im znacząca funkcja - przekaziciela historii, kultury, tradycji i życiowej mądrości.

W wieku XIX za sprawą m.in. L. A. Queteleta dostrzeżono starość jako problem społeczny. Próbowano za pomocą metod empirycznych określić właściwości fizyczne, duchowe i obyczajowe ludzi starych. Prowadzone były także pierwsze systematyczne studia nad chorobami starości, które skutkowały traktowaniem ludzi starych jako bezużytecznych i zbędnych. Pozytywną konsekwencją takiego postrzegania starości był rozwój opieki instytucjonalnej nad ludźmi starymi. Niestety, istniejące programy działań nie uwzględniały realnych i indywidualnych potrzeb i utożsamiały okres późnej dorosłości z niesamodzielnością i potrzebą pomocy.

Wiek XX, a wraz z nim procesy demograficzne związane ze zjawiskiem starzenia się społeczeństw spowodowały ponowny rozkwit badań nad starością. Tematykę późnej dorosłości podjęły obok nauk przyrodniczych, biologicznych i medycznych także takie dziedziny nauki, jak: socjologia, psychologia, polityka społeczna i pedagogika. W konsekwencji burzliwej sytuacji politycznej, ekonomicznej i społecznej zmianie uległy wzory i wartości społeczne [Tyszka, 2001: 17], sposoby myślenia o rodzinie i jej funkcjach, a także spojrzenie na człowieka starego i jego rolę w życiu rodzinnym [Halicka, 1995: 44].

Obecnie - w dobie dominacji tzw. modelu rodziny małej, zanikania rodzin wielopokoleniowych, postępu technologicznego, kryzysu wartości zmienia się rola i miejsce człowieka starego w rodzinie i społeczeństwie. Wprawdzie korzysta się z jego pomocy przy realizowaniu obowiązków dnia codziennego (m.in. opieki nad wnukami, pomocy w prowadzeniu gospodarstwa domowego), docenia przekazywanie wiedzy na temat wartości i zasad etycznych, własnego życia oraz życia rodziny, to jednak coraz częściej deprecjonuje się rolę i znaczenie ludzi starych. W ostatnich latach zauważa się upowszechnianie w społeczeństwie negatywnego wizerunku osoby starszej oraz coraz większą marginalizację najstarszego pokolenia zarówno w rodzinie, jak i społeczeństwie [Sidorczuk, 2011: 329]. Nie sprzyja to ani sytuacji osób starszych, ani relacjom międzygeneracyjnym, co potwierdzają prowadzone na ten temat badania i analizy. 


\section{Postrzeganie starości i ludzi starych}

W ostatnich latach - o czym była już mowa - status społeczny osób starszych ulega osłabieniu. Sytuacja ta stanowi m.in. skutek funkcjonowania negatywnych przekonań na temat starości i człowieka starego, gwałtownych przemian społecznych, a także braku wiedzy z zakresu funkcjonowania osób starszych. Analizy i opracowania na temat stereotypu starości i człowieka starego w społeczeństwie podkreślają izolację, samotność, zależność i potrzebę pomocy ${ }^{3}$. Przedstawiają starość, która jawi się na ogól jako negatywny etap życia, oparty na dalekich od rzeczywistości stereotypach i uogólnieniach. Negatywny stereotyp funkcjonujący w społeczeństwie stanowi odzwierciedlenie sytuacji ludzi starych, gdyż przedstawia wyobrażenia społeczeństwa, jego stosunek oraz myślenie na temat starości [Wawrzyniak, 2007: 68-73]. Stereotyp ten nie uwzględnia heterogeniczności starości, rozumienia tego okresu jako pełnego wieloznaczności i różnie przez osoby starsze przeżywanego. Niesłusznie okres późnej dorosłości łączy się zazwyczaj ze złym stanem zdrowia, niedołężnością oraz zależnością od innych, pomijając przy tym fakt istnienia całkiem licznej grupy osób starszych cieszących się dobrym staniem zdrowia i aktywnością. Co prawda współcześnie przypisuje się osobom starszym takie cechy, jak: wiedza, mądrość życiowa, cierpliwość, doświadczenie, autorytet, jednak znacznie rzadziej przyznaje się im pozycję równorzędną z innymi grupami wieku.

W literaturze przedmiotu na próżno szukać kompatybilnych badań na temat postrzegania osób starszych i relacji międzypokoleniowych. Zazwyczaj badacze skupiają się nad badaniem jednej generacji w obrębie rodziny. W związku z czym trudno o formułowanie ogólnych wniosków na temat postrzegania osób starszych i starości w ogóle. Analizy prowadzonych w Polsce badań pozwalają jednak stwierdzić, iż nie ma zgodności, co do postrzegania roli i znaczenia człowieka starego przez młodsze grupy. A wyłaniający się stereotyp starości i człowieka starego w społeczeństwie jest na ogół negatywny.

Ogólnopolskie analizy i opracowania wskazują wprawdzie, iż większość Polaków dostrzega rolę i znaczenie najstarszej generacji [Wądołowska, 2009: 10], jednak opinie te nie pokrywają się znacząco ze społecznymi

3 Badania prowadzone m.in. przez J. Rembowskiego [1984], M. Susułowską [1989], Z. Szarotę [2004] i innych, a także TNS OBOP i CBOS. Badania i analizy dotyczące postrzegania starości i człowieka starego znaleźć można w następujących pozycjach wskazanych autorów: [Rembowski, 1984; Susułowska, 1989; Szarota, 2004, a także: K. Kowalczuk (oprac.) 2012; K. Wądołowska (oprac.) 2009; J. Szczepańska (oprac.) 2008. 
przekonaniami na temat osób starszych i starości. Najbardziej przychylne ludziom starym jest średnie pokolenie, a osoby starsze doceniane są przez nie przede wszystkim ze względu na pomoc okazywaną $w$ opiece nad wnukami oraz wiedzę i doświadczenie. Negatywne skojarzenia dotyczące starości przejawia niemal co dziesiąta osoba, koncentrując się głównie na sytuacji zdrowotnej osób starszych oraz ich zależności od innych osób [Wądołowska, 2009: 3], a najmniej przychylne nastawienie wobec ludzi starych przejawiają dzieci i młodzież.

Przekonania na temat starości i osób starszych prezentowane przez dzieci i młodzież stanowią kwestie szczególnie ważną. Okres dzieciństwa i dorastania to czas kształtowania i osiągania pełnej struktury osobowości, tworzenia własnej hierarchii wartości i celów, określania swojego miejsca w świecie. A zatem jest to etap decydujący dla powstawania poglądów i przekonań na temat otaczającej rzeczywistości, ludzi, zjawisk, a więc także tych dotyczących człowieka starego i starości. Dzieciństwo i okres dorastania to czas, w którym można najpełniej oddziaływać na osobowość, postawy i zachowanie dzieci i młodzieży [Lawrence, Oliver, 2002: 32], stąd istotna jest analiza sposobu postrzegania ludzi starych i starości przez najmłodszą generację, by następnie móc wzmacniać i kształtować wzajemne relacje pomiędzy najmłodszymi i seniorami, a tym samym kształtować właściwe postawy względem ludzi starych.

Niestety, najmłodsi wypowiadają się na temat starości i człowieka starego raczej negatywnie. Ludzie starzy jawią się jako osoby schorowane, niesamodzielne, smutne, samotne, potrzebujące pomocy, a także nadużywające przywilejów, m.in. takich jak tańsze przejazdy komunikacją publiczną oraz jako te, które nie wnoszą wystarczających zasobów w funkcjonowanie służby zdrowia, rynku pracy oraz ubezpieczeń społecznych i zdrowotnych [Susułowska, 1989: 49; Halicka, Halicki, 2011: 18; Wądołowska, 2009: 3]. Wśród atrybutów osób starszych dzieci i młodzież wymieniają: biedę, bezradność, rezygnację, izolację, niepełnosprawność oraz śmierć. W świadomości młodzieży „stary” nierzadko oznacza gorszy, słaby i brzydki, a ludzie starzy postrzegani są jako bierni, roszczeniowi, niechętni zmianom oraz koncentrujący swoje życie wokół własnej osoby. Podejmowane przez seniorów aktywności kojarzone są na ogół z opieką nad wnukami, pracą w gospodarstwie domowym, praktykami religijnymi oraz pomocą rodzinie. Działania te nie zyskują jednak aprobaty, gdyż nie są łączone z pracą społeczną, realizowaniem pasji, podróżowaniem i innymi zajęciami cieszącymi się uznaniem ludzi młodych [Krupa, 2012: 38]. Młodzież rzadko myśli o starości, co u części z nich powoduje awersję do wy- 
powiadania się na temat tego okresu życia, a także trudność w odnajdywaniu pozytywnych aspektów życia w starości, przez co nie sprawia im przyjemności obcowanie z osobami starszymi [Śliwa, 2010: 100].

Mimo, iż starość na ogół postrzegana jest negatywnie przez pryzmat zmniejszających się możliwości fizycznych ludzi starszych oraz zmian dokonujących się w procesach poznawczych, to niektóre analizy [Kozdroń, Kozdroń, 2008; Maciantowicz, 2006] dostarczają optymistycznych informacji, wskazując, iż część młodzieży myśli o seniorach pozytywnie, dostrzegając ich rolę i znaczenie. Ci młodzi ludzie twierdzą, iż starość i młodość to dwa różne etapy życia, które doskonale się uzupełniają, stwarzając pokoleniom okazję, by uczyć się od siebie wzajemnie. Osoby starsze bywają postrzegane jako: rozsądne, szczere, odpowiedzialne, uczciwe oraz poważne. W sferze emocjonalnej osoby starsze uchodzą za spokojne, opanowane, ale też przewrażliwione, nieco rzadziej zaś za wesołe i pełne humoru. Młodzież w kontaktach z osobami starszymi odczuwa ich życzliwość, zaufanie, chęć do współpracy i uczynność. Najbardziej znaczącą wartością wynikającą z relacji z osobami starszymi okazuje się być natomiast poczucie, że jest się kochanym oraz uzyskanie podstaw wiary religijnej i zasad moralnych [Szczepańska, 2008: 4]. Dla wielu osób babcia i dziadek stanowi źródło wiedzy o dziejach rodziny, niektórych wydarzeniach historycznych oraz patriotyzmie. Część dzieci i młodzieży podkreśla, iż zawdzięcza dziadkom cechy charakteru takie, jak: obowiązkowość, pracowitość, samodyscyplinę i silną wolę. Nieco rzadziej wskazywana bywa rola dziadków w rozbudzaniu miłości do ojczyzny, przekazywaniu umiejętności praktycznych, czy kształtowaniu zainteresowań [Kowalczuk, 2012: 16].

Dostrzega się więc pewną ambiwalencję w poglądach dzieci i młodzieży na temat starości i ludzi starych. Z jednej strony wskazują oni na negatywne aspekty starości i nieprzyjemne atrybuty osób starszych, z drugiej zaś są wśród nich tacy, którzy opowiadając o ostatnim etapie ludzkiego życia oraz osobach go przeżywających z sympatią i uznaniem. Sposób budowania wyobrażeń jest bowiem związany z wieloma czynnikami, m.in. wiekiem, sytuacją życiową, relacjami rodzinnymi, czy też częstotliwością kontaktów z ludźmi starymi. Równie istotna jest także wiedza dotycząca funkcjonowania osób starszych oraz świadomość na temat ich sytuacji życiowej, problemów i trudności. Brak obiektywnych informacji i kompetencji, a tym samym mało przychylne postrzeganie ludzi starych wynika $\mathrm{z}$ „braku pozytywnej przestrzeni do spotkania, blisko domu: świetlica, dom kultu- 
ry, spółdzielnia"4. Społeczna przestrzeń, w której dostrzegalny jest deficyt miejsca na międzypokoleniowe kontakty, w trakcie których wszystkie generacje mogłyby nabywać wiedzę o sobie, stanowi duże ograniczenie dla przejawianych opinii oraz międzypokoleniowych kontaktów.

Nastawienie do ludzi starych w społeczeństwie objaśniają trzy teorie, tj. teoria wymiany, teoria społecznego załamania oraz międzypokoleniowej solidarności i konfliktu. Każda z nich w nieco odmienny sposób wskazuje mechanizmy powstawania negatywnych przekonań na temat starości i ludzi starych. I tak teoria wymiany traktuje życie społeczne jako rodzaj transakcji pomiędzy ludźmi, bazującej na społecznej wymianie. Jednostka wchodząc w interakcje dokonuje kalkulacji kosztów i zysków. Ludzie wybierają te sytuacje, które związane są z jak największym zyskiem i najmniejszymi kosztami, czyli angażują się w relacje opłacalne, a wycofują się z tych nazbyt kosztownych. Sytuację tę akceptują młodsze pokolenia, $\mathrm{z}$ perspektywy których kontynuowanie relacji z najstarszą generacją staje się kosztowne. Seniorzy, mając mniej siły w konfrontacji z osobami młodszymi ze względu na mniejsze zasoby, zmniejszają swój udział w życiu społecznym. Dochodzi więc do ograniczenia wzajemnych kontaktów i odsuwania ludzi starych na obrzeża życia społecznego, a także etykietowania ich jako mało przydatnych i niekompetentnych.

$\mathrm{Na}$ źródła mało przyjemnej sytuacji seniorów wskazuje również teoria społecznych kompetencji i społecznego załamania. Teoria opisuje pojęcie zwane syndromem załamania społecznego, przejawiające się $\mathrm{w}$ procesie, w którym podatna na zranienie jednostka otrzymuje negatywne komunikaty ze swojego środowiska społecznego, a które inkorporuje do wizji samego siebie, powodując niebezpieczną spiralę sprzężenia zwrotnego [Halicki 2006: 263]. Osoby starsze stają się podatne na zranienie ze względu na utratę roli, negatywne stereotypy związane ze starzeniem się, czy też doświadczaniem innych kryzysów (np. związanych ze zdrowiem). Wskazana sytuacja prowadzi do etykietowania osób starszych przez środowisko społeczne, w którym żyją - rodzinę, sąsiadów, społeczność lokalną - przez co postrzegają siebie w sposób, w jaki odbiera je środowisko, czyli jako osoby chore, niekompetentne. Przekonania tkwiące w społeczeństwie oddziaływują na ludzi sta-

4 Prezentacja z badania jakościowego przeprowadzonego przez Dom Badawczy „Maison” dla Rzecznika Praw Obywatelskich pt. „Osoby starsze w oczach młodzieży, młodzież w oczach osób starszych”, zaprezentowana 16.06.2012 roku w Warszawie podczas konferencji pt. „Osoby starsze w oczach młodzieży, młodzież w oczach osób starszych”, http://www.rpo.gov.pl/pliki/134011 98100 (dostęp: 20.01.2015). 
rych w taki sposób, że są skłonni wycofać się z bolesnych interakcji społecznych, a także poszukiwać motywów niewłaściwego zachowania innych we własnych ograniczonych możliwościach i zasobach. Dodatkowo wzmacnia to negatywny stereotyp starości w zbiorowościach, a nieprzychylne nastawienie wielu grup społecznych - w tym dzieci i młodzieży - do ludzi starych i starości oraz rezygnacja z podejmowania z nimi relacji nasilają się.

Relacje pomiędzy pokoleniami tłumaczy także model międzypokoleniowej solidarności i konfliktu (solidarity (and conflict) model of generational relations) zaproponowany przez V. L. Bengtsona i współpracowników [Antonucci, Jackson, Biggs, 2007: 681]. Koncepcja ta skupia się na pojęciu solidarności odczuwanej przez przedstawicieli różnych pokoleń, która interpretowana jest przez tzw. udział w kształtowaniu wzajemnych relacji. Zakłada się, iż starsza generacja ma większy wkład w funkcjonowanie grup społecznych (np. rodziny) i kształtowanie międzygeneracyjnych relacji niż młodsze pokolenia. Manifestowane jest to silniejszym wyrażaniem poczucia solidarności przez seniorów i większą wyrozumiałością w stosunku do pozostałych pokoleń. Natomiast konflikt, który jest związany z mniejszym poczuciem wspólnoty jest częściej ujawniany przez młodsze generacje. Konflikt wydaje się wynikać z poszukiwania przez ludzi młodych innych niż grupa seniorów sieci wsparcia. Może też budzić zdziwienie i niekiedy brak zrozumienia w przypadku pozostałych pokoleń. Koncepcja ta tłumaczy więc negatywny stereotyp starości i człowieka starego wśród dzieci i młodzieży. Pokolenie to w mniejszym stopniu odczuwa znaczenie międzygeneracyjnych więzi, co rodzi niezrozumienie dla potrzeb seniorów związanych z międzypokoleniową solidarnością. Nieporozumienia pojawiają się bowiem na skutek innego spojrzenia - wynikającego z naturalnych procesów zachodzących w życiu generacji - na rolę i znaczenie międzygeneracyjnych kontaktów. Jednak niedyskutowane potrzeby i oczekiwania mogą rodzić wzajemne niezrozumienie, co silniej manifestowane jest przez ludzi młodych, ze względu na ich mniejsze doświadczenie i dystans do wielu sytuacji. Może się to właśnie przejawiać w niekorzystnym postrzeganiu starości i człowieka starego.

W konkluzji niniejszych rozważań podkreślić należy, iż starość i ludzie starzy postrzegani są różnie, aczkolwiek na ogół mało przychylnie i na podstawie mało obiektywnej wiedzy i informacji. Odnosząc się jednak do zaprezentowanych koncepcji, takie ujmowanie tego okresu życia jest zjawiskiem nieodłącznie wpisanym w rzeczywistość i wynika z mechanizmów charakterystycznych, a zarazem naturalnych dla grup i szerszych zbiorowości. Stanowi tym samym nierozłączny atrybut społeczności, a zarazem zadanie i wyzwanie, 
by starość i człowieka starego wprowadzać w świat życia społecznego z całym, różnorodnym repertuarem cech, zachowań, problemów i możliwości.

\section{Starość i jej wymiary w opiniach dzieci i młodzieży}

Wymiary starości rysujące się $\mathrm{w}$ opiniach dzieci i młodzieży korespondują ze sposobem postrzegania przez nich tego okresu życia oraz ludzi starych. W swoich wypowiedziach nawiązują do starości biologicznej, psychicznej i społecznej. Jednak w ich opisie uwidacznia się na ogół jednokierunkowe ujmowanie każdej sfery życia. Zazwyczaj koncentrują się na zmianach mało pozytywnych, częściej brakach i trudnościach niż na rozwojowych potencjałach i możliwościach. Ich wiedza, oparta głównie na obserwacji, mimo iż koncentruje się jedynie na selektywnie dostrzeganych faktach, jest wiedzą bliską rzeczywistości i odpowiadającą zarysowanym w literaturze atrybutom starości.

Dzieci i młodzież najczęściej rozpatrują starość w odniesieniu do osób znajdujących się pomiędzy 50 a 66 rokiem życia oraz do zmian natury biologicznej, które zachodzą w organizmie człowieka. Mówiąc o starości podkreślają, iż rozpoczyna się ona wówczas, gdy nasilają się kłopoty ze zdrowiem oraz następuje utrata sił fizycznych, a tym samym postępująca niesprawność oraz spowolnienie ruchów. Prowadzi do dalej do niedołężności i niepełnosprawności. W okresie tym dokonuje się ponadto utrata urody, co przejawia się pomarszczoną skórą, siwiejącymi i siwymi włosami oraz przygarbioną sylwetką. Ludzie starzy w związku z tym potrzebują atrybutów (np. okularów, laski, aparatów słuchowych), umożliwiących im funkcjonowanie w starości, które jednak postrzegane są przez dzieci i młodzież jako odpychające. $\mathrm{W}$ opiniach najmłodszych nie pojawiają się w zasadzie spostrzeżenia dotyczące aktywnego i sprawnego przeżywania ostatniego etapu życia człowieka.

Starość psychiczna zgodnie charakteryzowana jest przez utratę motywacji i osłabienie zdolności poznawczych, a także spowolnienie procesów poznawczych (uwagi, pamięci). Ponadto, dzieci i młodzież dostrzegają, że w starości następuje ograniczenie osobistej autonomii w zakresie możliwości poznawczych, co zmusza ludzi starych do korzystania z pomocy i wsparcia innych osób. W kontekście cech opisujących ludzi starych widoczna jest pewna ambiwalencja. Z jednej strony starości przypisuje się mądrość życiową, doświadczenie, racjonalizm w myśleniu i poglądach, odpowiedzialność, konstruktywną refleksyjność, opanowanie. Częściej zaś w jej opisie pojawiają się, niestety, takie określenia, jak: smutek, malkontenctwo, zrzędliwość, zagubie- 
nie, roszczeniowość oraz wygórowane, nierealistyczne oczekiwania. Język, jakim posługuje się najmłodsza generacja rozmawiając o starości psychicznej, często bywa nieprzyjemny, oceniający, a nawet agresywny. Uwidacznia mało przychylne nastawienie dzieci i młodzieży do zmian w tym zakresie, a także podkreśla znaczenie i wagę sprawności intelektualnej w kontaktach z nimi.

$\mathrm{W}$ aspekcie społecznym starość łączona jest $\mathrm{z}$ zależnością od innych, na ogół młodszych generacji oraz nadużywaniem przywilejów (m.in. komunikacyjnych, ubezpieczeniowych, zdrowotnych). Ludzie starzy zaś postrzegani są jako samotni i społecznie izolowani, biedni i zależni finansowo, a także jako na ogół bierni i pasywni. Starość społeczna wzbudza więc nierzadko obawy najmłodszej generacji oraz strach i niepokój, który powoduje odsuwanie myślenia o tym okresie życia oraz ludziach starych jako przedstawicielach naturalnego etapu życia. Mimo towarzyszących dzieciom i młodzieży odczuć w sposób precyzyjny i adekwatny opisują oni przypisane osobom starszym role. Najstarsze pokolenie jawi się jako otaczający miłością dziadkowie, opiekunowie, emeryci, nauczyciele (miłości, wiary, zasad moralnych, wartości). Sposób opisu ról osób starszych jest na ogół pełen sympatii i życzliwości, a dokonując go dzieci i młodzież wspominają swoich bliskich, czyli własnych dziadków, krewnych, a niekiedy sąsiadów.

Dostrzega się, że dzieci i młodzież, mimo przejawiania mało optymistycznych opinii na temat starości, potrafią opisywać ją w odniesieniu do cech i atrybutów, tworzących jej wymiary. Na ogół interpretują starość przez pryzmat cech biologicznych, dotyczących zmian fizycznych o charakterze stricte regresywnym, nie dostrzegając przemian rozwojowych w kierunku progresywnym. Starość w wymiarze psychicznym jawi się już jednak jako starość zróżnicowana, która przebiega różnie u poszczególnych jednostek. W sferze społecznego funkcjonowania dzieci i młodzież obserwują zaś w starości stagnację i pasywizm, doceniając przy tym role osób starszych, które podejmują. Wskazuje to, że oni nie są przygotowani do postrzegania starości jako kolejnej, naturalnej fazy życia ze wszystkimi jej przejawami, nie posiadają bowiem obiektywnej, wieloaspektowej wiedzy na temat starości i funkcjonowania człowieka starego, a opisując starość odwołują się głównie do jednej sfery - sfery biologicznej.

\section{Zakończenie}

Starość, mimo iż stanowi okres życia, o którym pisano już w starożytności, nadal nastręcza pewnych trudności definicyjnych i deskryptywnych. 
Jak nie ma jednoznacznej definicji tego etapu, tak różnie bywa opisywany i postrzegany nie tylko przez członków różnych zbiorowości, ale niekiedy i przedstawicieli poszczególnych dziedzin nauki. Nierzadko wzbudza niepokój i obawy, gdyż dostrzega się w nim przewagę procesów regresywnych nad progresywnymi, zapominając o umiejętnościach osób starszych do kompensowania powstających braków oraz możliwościach radzenia sobie z pojawiającymi się trudnościami. Stąd też sposób postrzegania i opisywania starości i jej wymiarów bywa często mało obiektywny. Tym samym dzieci i młodzież posiadający najmniejsze doświadczenie w kwestii obcowania $\mathrm{z}$ osobami starszymi prezentują najmniej życzliwe i holistyczne nastawienie do najstarszego pokolenia.

Starość w percepcji dzieci i młodzieży postrzegana jest w odniesieniu do trzech wymiarów - biologicznego, psychicznego i społecznego. Ujęcie to bliskie jest rzeczywistości, jednak nie do końca adekwatnie oddaje charakterystykę starości. Spojrzenie dzieci i młodzieży jest jednowymiarowe i koncentruje się przede wszystkim na kwestiach mało przyjemnych, nie odwołując się do możliwości i szans rozwojowych. Nierzadko też najmłodsze pokolenie bardziej przychylnie spostrzega starość przeżywaną przez bliskich niż osoby im obce, nieznane. Postrzegają oni starość jako okres trudny, bo związany z chorobami, utratą sił i urody, nierzadko też brakiem sprawności, co w konsekwencji prowadzi do zależności i konieczności korzystania z pomocy innych osób. Jest to także czas osłabienia i spowolnienia procesów poznawczych, a tym samym ograniczenia osobistej autonomii. W wymiarze starości psychicznej dzieci i młodzież dostrzegają jednak pewne różnice w funkcjonowaniu seniorów i zakładają, że część z nich cechuje się mądrością, doświadczeniem, opanowaniem. Doceniają przy tym własnych dziadków za pomoc w ich wychowaniu, czy też kształtowaniu cech i umiejętności.

Dokonane analizy wskazują na konieczność podejmowania działań zmierzających do przekazywania dzieciom i młodzieży właściwej, obiektywnej wiedzy na temat wymiarów starości i funkcjonowania ludzi starych, ich możliwości, kompetencji, trosk i problemów. Oswajanie ze starością poprzedzone przekazem informacji, nie tylko zwiększy świadomość na temat ostatniego okresu życia i pozwoli spoglądać na ten etap i doświadczające je osoby w sposób bardziej życzliwy, ale może zmieniać myślenie, poglądy oraz zachowania względem najstarszej generacji.

Szczególne znaczenie w procesie kształtowania właściwych stosunków pomiędzy pokoleniami odgrywa edukacja gerontologiczna, realizowana w środowisku wychowawczym. Mowa tu o intencjonalnych, a zarazem nie- 
zamierzonych działaniach podejmowanych w instytucjach opiekuńczo-wychowawczych (tj. szkole, świetlicach środowiskowych, domach kultury), a ukierunkowanych przede wszystkim na uczniów, a także wychowawców, rodziny, czyli całą społeczność lokalną. Działania te zmierzać powinny do tworzenia takich sytuacji wychowawczych, w których jednostki - głównie dzieci i młodzież - nabędą kompetencje istotne dla nawiązywania i podtrzymywania kontaktów z seniorami. A przywołując słowa S. Biggsa - tak rozumiana edukacja - umożliwić może ukształtowanie przekonania, że „wszyscy znajdujemy się na tej samej łodzi, która stanowi zachętę do wzajemnej solidarności, rozpoznawania wspólnych interesów, a także do identyfikowania szczególnych wartości, które niesie ze sobą każda grupa wieku" [Biggs, 2008: 118-119].

\section{Bibliografia}

Antonucci T. C.,. Jackson J. S, Biggs S. (2007), Intergenerational Relations: Theory, Research and Policy, "Journal of Social Issues", t. 63, nr 4.

Biggs S. (2008), Aging in a critical world: The search for generational intelligence, "Journal of Aging Studies", t. 22, nr 2.

Bois J. P. (1996), Historia starości. Od Montaigne'a do pierwszych emerytur, Warszawa, Oficyna Wydawnicza Volumen, Wydawnictwo Marabut.

Halicka M. (1995), Historyczna zmienność traktowania starości, „Gerontologia Polska”, nr $3 / 4$.

Halicka M., Halicki J. (2011), Opinie polskich seniorów na temat starości i przygotowania się do niej, „Polityka Społeczna”, nr specjalny Aspekty medyczne, psychologiczne, socjologiczne i ekonomiczne starzenia się ludzi w Polsce.

Halicka M., Halicki J. (2002), Integracja społeczna i aktywność ludzi starszych, (w:) B. Synak (red.), Polska starość, Gdańsk, Wydawnictwo Uniwersytetu Gdańskiego.

Halicki J. (2006), Społeczne teorie starzenia się, (w:) M. Halicka, J. Halicki (red.), Zostawić ślad na ziemi, Białystok, Uniwersytet w Białymstoku.

Kowalczuk K. (oprac.), (2012), Rola dziadków w naszym życiu, Warszawa, CBOS, http:// cbos.pl/SPISKOM.POL/2012/K_008_12 (dostęp: 10.06.2015).

Kamiński A. (1965), Czas wolny i jego problematyka społeczno-wychowawcza, WrocławWarszawa-Kraków, Zakład Narodowy im. Ossolińskich.

Klonowicz S. (1979), Oblicza starości, Warszawa, Wiedza Powszechna.

Kozdroń A., Kozdroń E., Nowak P. (2008), Osoby starsze w opinii studentów, (w:) J. T. Kowaleski, P. Szukalski (red.), Pomyślne starzenie się $w$ perspektywie nauk społecznych i humanistycznych, Łódź, Uniwersytet Łódzki. 
Krupa B., (2012), Starość w percepcji młodzieży - perspektywa pedagogiczna, „Nowiny Lekarskie", nr 1.

Lawrence A. P., Oliver P. J. (2002), Osobowość. Teoria i badania, Kraków, Wydawnictwo Uniwersytetu Jagiellońskiego.

Maciantowicz E. (2006), Poglądy współczesnej młodzieży na starzenie się i starość, (w:) S. Steuden, M. Marczuk (red.), Starzenie się a satysfakcja z życia, Lublin, Wydawnictwo Katolickiego Uniwersytetu Lubelskiego.

Minois G. (1995), Historia starości. Od antyku do renesansu, Warszawa, Wydawnictwo Marabut.

Prezentacja z badania jakościowego przeprowadzonego przez Dom Badawczy „Maison” dla Rzecznika Praw Obywatelskich pt. „Osoby starsze w oczach młodzieży, młodzież w oczach osób starszych", zaprezentowana dnia 16.06.2012 r. w Warszawie podczas konferencji pt. „Osoby starsze w oczach młodzieży, młodzież w oczach osób starszych”, dostępna na stronie: http://www.rpo.gov.pl/pliki/134011 98100 (dostęp: 20.01.2015).

Rembowski J. (1984), Psychologiczne problemy starzenia się człowieka, Poznań, Państwowe Wydawnictwa Naukowe.

Sidorczuk A. (2011), Edukacyjna rola ludzi starych w rodzinie - dawniej i dziś, (w:) A. Cudowska (red.), Kierunki rozwoju edukacji w zmieniajacej się przestrzeni społecznej, Białystok, Wydawnictwo Trans Humana.

Stuart-Hamilton I. (2006), Psychologia starzenia się. Wprowadzenie, Poznań, Wydawnictwo Zysk i S-ka.

Susułowska M. (1989), Psychologia starzenia się i starości, Warszawa, Państwowe Wydawnictwo Naukowe.

Szarota Z. (2004), Gerontologia społeczna i oświatowa: zarys problematyki, Kraków, Wydawnictwo Naukowe Akademii Pedagogicznej.

Szatur-Jaworska B. (2006), Faza starości w cyklu życia człowieka - ogólna charakterystyka, (w:) B. Szatur-Jaworska, P. Błędowski, M. Dzięgielewska (red.), Podstawy gerontologii społecznej, Warszawa, Oficyna Wydawnicza ASPRA-JR.

Szczepańska J. (oprac.), (2008), Co im zawdzięczamy? Opinie w przeddzień święta babć i dziadków, Warszawa, CBOS, http://www.cbos.pl/SPISKOM.POL/2008/K_003_08 (dostęp: 12.08.2015).

Śliwa S. (2010), Postawy osób młodych (studentów) wobec starzejących się osób, (w:) S. Rogala (red.), Starość i jej konsekwencje społeczno-rodzinne, Opole, Wydawnictwa Wyższej Szkoły Zarządzania i Administracji.

Tyszka Z. (2001), Stan i przeobrażenia rodzin polskich na przełomie wieków XX $i$ XXI. Niedawna przeszłość i teraźniejszość, (w:) Z. Tyszka (red.), Współczesne rodziny polskie - ich stan i kierunek przemian, Poznań, Wydawnictwo Naukowe Uniwersytetu im. A. Mickiewicza w Poznaniu.

Wawrzyniak J. (2007), Funkcjonowanie stereotypu starości w społeczeństwie, „Gerontologia Społeczna”, nr 1(2).

Wądołowska K. (oprac.), (2009), Polacy wobec ludzi starszych i własnej starości, Warszawa, CBOS, http://www.cbos.pl/ SPISKOM.P OL/2009/K_157_09 (dostęp: 12.08.2015). 
SUMMARY

\section{Dimensions of old age in the perception of children and adolescents}

This article concerns the dimensions of old age in the perception of children and adolescents. The inspiration for its creation was the analysis of explorations of the perception of old age and old people in society, especially in perception of children and adolescents. This issue is a significant problem because analyzes and reports on the subject, emphasize that the least favorable attitudes towards the elderly manifests indicated young generation. Children and adolescents usually speak out not very friendly about old age and the old people and build their opinions on the basis of generally negative stereotype of old age and the old people in the society. Hence, it is interesting to present dimensions of old age formed by the younger generation because they become important for establishing and building intergenerational contacts and relationships. Repeatedly these dimensions which are relying on the little benevolent and not always accurate information prevent mutual and shared communion of both generations. Awareness of their specificity is important to take action aimed at the direction of formation of relevant attitudes toward the old man and old age.

\section{Keywords:}

old age, dimensions of old age, old people, perception of old age and old people 